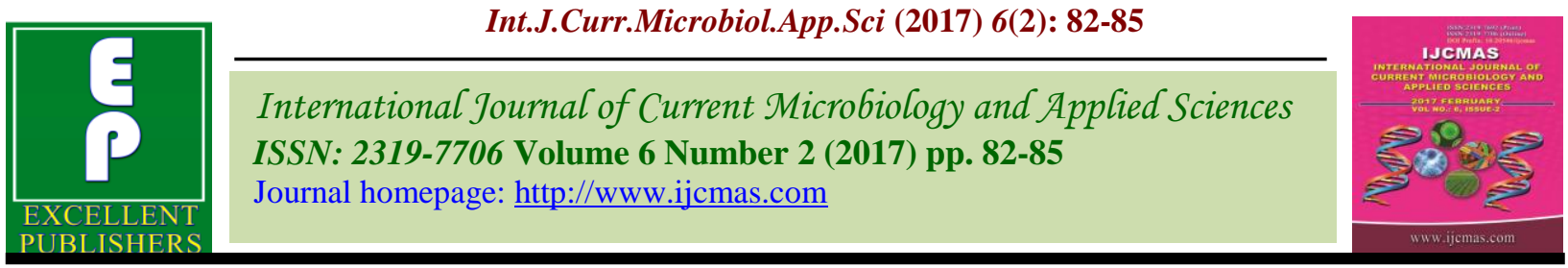

Original Research Article

http://dx.doi.org/10.20546/ijcmas.2017.602.011

\title{
Studies on Yield Potential of Vermicompost by using Eisenia foetida in Different Solid Waste Materials
}

\author{
M. Babita Devi* \\ Department of Botany, Naorem Birahari College, Khundrakpam, Imphal East, Manipur, India \\ *Corresponding author
}

A B S T R A C T

Keywords

Solid wastes,

Cowdung,

Eisenia foetida,

Vermicompost,

Yield potential.

Article Info

Accepted:

05 January 2017

Available Online:

10 February 2017
The present study was to determine the conversion of six different solid waste materials viz. kitchen waste, paddy straw, leaf litters, Azolla plant, Cyathula plant and mixed sawdust from local mills into vermicompost and their yield potential by using earthworm species Eisenia foetida. $5 \mathrm{~kg}$ dry weight of each waste material were mixed with cow dung and allowed to undergo decomposition. The maximum yield of vermicompost were recorded from the leaf litters (3.937 kg dry wt.) followed by Azolla plant (3.655 kg dry wt.). The lowest vermicompost yield was recorded from Cyathula plant (2.387 kg dry wt.) respectively.

\section{Introduction}

With increase in human population and greater demands, there is an increase in production of various types of waste materials viz. agricultural, domestic, city or municipal and industrial. These generated waste materials are disposed without concerning alarming environmental issues causing environmental pollution, affecting ambient air quality, surface water bodies, underground water sources and soil. These give sufficient scope for health hazards, sickening of soil and contamination of air and water. Therefore, the disposal of different types of waste materials has become very important issue for maintaining healthy environment (Senapati and Julka, 1993; Moorthi et al., 2016). The most apparent approach of management is to at least recycle the decomposable organic wastes into a useful product by utilizing earthworm activities. The feeding and general behaviour activities of earthworms like burrowing, micronising, digesting and excreting support the decomposition of biodegradable matters. These activities decompose complex waste matters to simple forms and the process is known as vermicompost.

Vermicomposting is an eco-biotechnological process that transforms energy rich and complex organic substances into stabilized vermicompost (Bentize et al., 2000). Meena and Ajay (2011) use vegetable wastes amended with cattle manure for 
vermicomposting. Vermicomposting of kitchen wastes and certain other organic wastes has been proved successful (Daniel and Karmegan, 1999; Suthar, 2009; Alok Bharatwaj, 2010). The promising technique that can be applied to treat the waste materials is vermicomposting by some specific composting worms that have been appeared as key sources to combat the problem of organic waste disposal on a low input basis (Garg and Kaushik, 2005; Suthar, 2007). Hence, the aim of study was to determine the yield potential of vermicompost prepared from different solid waste materials by using Eisenia foetida.

\section{Materials and Methods}

\section{Collection of earthworm}

An identified Eisenia foetida species were collected from Central Agricultural University (CAU), Iroishemba and then reared in plastic tubs in vermicomposting shed under natural conditions for further experimental analysis.

\section{Collection of waste materials}

6(six) solid wastes viz. kitchen waste, paddy straw, leaf litters, Azolla plant, Cyathula plant and mixed sawdust from local mills were collected and sundried.

\section{Experimental setup for vermicomposting}

The experiment for vermicomposting was conducted in plastic buckets. $5 \mathrm{~kg}$ dry weight of each 6(six) waste materials with cow dung (4:1 ratio) were put in the plastic buckets and allowed to undergo partial decomposition. Before partial decomposition, paddy straw and Cyathula plants were chopped to smaller pieces. Watering was done as and when required. These wastes were allowed to undergo partial decomposition for 15 days.
Four replicates of each six waste materials were taken for the experiment. Twenty five adult Eisenia foetida worms were introduced in each of the mixture of six waste materials. The vermibeds were covered with gunny bags to maintain the optimal moisture. The experiment was set under shady place to avoid direct sunlight. The vermibeds were monitored day by day.

Once in every 20 days, the top few inches of the bedding is turned over, allowing for escape of any build up gases and to prevent the bedding from becoming too densely packed.

\section{Collection of vermicompost}

Harvesting period of vermicompost were different for each six different waste materials. When the topmost layer appears brownish, the compost can then be harvested by scrapping off the upper layer periodically dried and separately stored.

\section{Results and Discussion}

The results on the effect of yield potential of vermicompost from six different waste materials are presented (Table1and Fig.1).The highest vermicompost yield were recorded from the leaf litters (3.937 kg dry wt.) followed by Azolla plant (3.655 kg dry wt.). The lowest vermicompost yield was recorded from Cyathula plant (2.387 kg dry wt.) respectively. According to Ambulkar and Shedkar (2004), the volume of the wastes can be reduced to $50-85 \%$ after composting. But still, there is no any reports of exact vermicompost yield from the organic wastes in comparison to the present study. Some workers studied only the conversion of organic wastes into valuable organic manure (Zajonc and Sidor, 1990; Mitchell and Edwards, 1997; Nagavallemma et al., 2006; Yadav and Garg, 2011; Vermi, 2011). 
Table.1 Yield potential of vermicompost from various solid waste materials by Eisenia foetida

\begin{tabular}{|l|l|c|c|c|}
\hline Sl. No. & \multicolumn{1}{|c|}{$\begin{array}{c}\text { Name of solid } \\
\text { wastes }\end{array}$} & $\begin{array}{c}\text { Initial dry wt. of } \\
\text { substrate }(\mathrm{kg})\end{array}$ & $\begin{array}{c}\text { Dry compost } \\
\text { recovered }(\mathrm{kg})\end{array}$ & $\begin{array}{c}\text { Compost } \\
\text { production }(\%)\end{array}$ \\
\hline 1. & Kitchen waste & 5 & 3.090 & 61.80 \\
\hline 2. & Paddy straw & 5 & 2.975 & 59.50 \\
\hline 3. & Azolla plant & 5 & 3.655 & 73.10 \\
\hline 4. & Leaf litters & 5 & 3.937 & 74.74 \\
\hline 5. & Cyathula plant & 5 & 2.387 & 47.74 \\
\hline 6. & Sawdust & 5 & 2.655 & 53.10 \\
\hline
\end{tabular}

Fig.1 Yield potential of vermicompost from various solid waste materials by Eisenia foetida

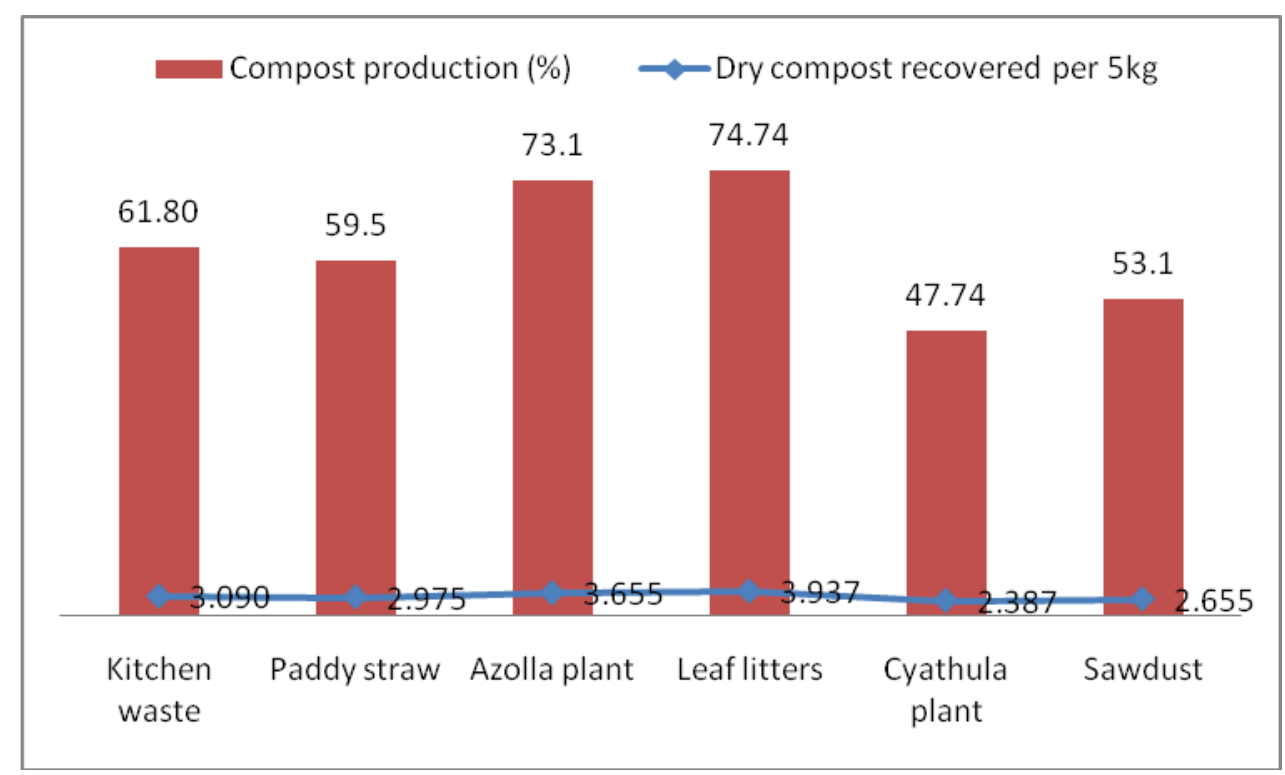

So, the outcome of the investigation clearly indicates that most of the solid waste materials have the ability of conversion into high rate of vermicompost yield. In conclusion, from the above study it has been concluded that selected six solid waste materials have the ability to produce high vermicompost yield by using earthworm species. On the other hand, utilization of these wastes channelize to minimize or avoid pollutional effect on the environment, in addition vermicompost exhibit a greater potential as organic biofertilizers for the growth and development of plant and it would earn immense economic benefit.

\section{Acknowledgement}

The author acknowledged the financial assistance supported by the Department of UGC, NERO, Government of India during the course of the study.

\section{References}

Alok Bharadwaj. 2010. "Management of kitchen waste material through vermicomposting". Asian J. Exp. Biol. Sci., 1(1): 175-177.

Ambulkar, A.R. and Shekdar, A.V. 2004. "Prospects of biomethanation 
technology in Indian context: a pragmatic approach". J. Res. Conservation and Recycling, 40(2): 111-128.

Bentize, E., R. Nogales, G. Masciandro and B. Ceccanthi. 2000. Isolation by isoelectric focusing of humic urease complex from earthworm Eisenia foetida processed sewage sludge. Biol. Fert. Soil, 31: 489-493.

Daniel, T. and Karmegam, N. 1999. Bioconversion of selected leaf litters using an African epigeic earthworm, Eudrilus eugeniae. Ecol. Environ. Conserv., 5: 273-277.

Garg, V.K. and Kaushik, P. 2005. Vermistabilization of textile mill sludge spiked with poultry droppings by an epigeic earthworm Eisenia foetida. Biores. Technol., 96: 1189-1193.

Khwairakpam Meena and Kalamdhad Ajay S. 2011. Vermicomposting of vegetable wastes amended with cattle manure. Res. J. Chem. Sci., Vol. 1(8): 49-56.

Mitchell, A. and Edwards, C.A. 1997. The production of vermicompost using Eisenia foetida from cattle manure. Soil Biol. Biochem., 29: 3-4.

Moorthi, M., Nagaranjan, K. and Senthilkumar, A. 2016. Vermitechnology of organic solid waste with using earthworm Eudrilus eugeniae. The J. Zool. Studies, Vol. 3(4): 48-51.

Nagavallemma, K.P., Wani, S.P., Stephane Lacroix, Padmaja, V.V., Vineela, C., Babu Rao, M. and Sahrawat, K.L. 2006.
Vermicomposting: Recycling wastes into valuable organic fertilizer. An Open Access Journal published by ICRISAT, 2(1): 16 Pp.

Senapati, B.K. and J.M. Julka. 1993. Selection of suitable vermicomposting species under Indian conditions. In: Earthworms Resources and Vermiculture. Zool. Survey of India, Calcutta, pp: 113-115.

Suthar, S. 2007. Vermicomposting potential of Perionyx sansbaricus in different waste material. Biores. Technol., 98(6): 1231-1237.

Suthar, S. 2009. Vermicomposting of vegetable market solid waste using Eisenia foetida: impact of bulking material on earthworm growth and decomposition rate. Ecol. Engi., 35: 914-920.

Vermi Co. 2001. Vermicomposting technology for waste management and agriculture: an executive summary. (http://www.vermico.com/summ.htm) PO Box 2334, Grants Pass, OR 97528, USA: Vermi Co.

Yadav, A. and Garg, V.K. 2011. Recycling of organic wastes by employing Eisenia foetida. Biores. Technol., 102: 28742880.

Zajonc, I. and Sidor, V. 1990. Use of some wastes for vermicompost preparation and their influence on growth and reproduction of the earthworm Eisenia foetida. Pol'nohospodars-tvo (CFFR), 36(8): 742-752.

\section{How to cite this article:}

Babita Devi, M. 2017. Studies on Yield Potential of Vermicompost by using Eisenia foetida in Different Solid Waste Materials. Int.J.Curr.Microbiol.App.Sci. 6(2): 82-85. doi: http://dx.doi.org/10.20546/ijcmas.2017.602.011 